\title{
ENGLISH LANGUAGE COMPETENCY AND OUTSOURCED CALL CENTERS IN BANGLADESH
}

\author{
Mizanur Rahman ${ }^{1}$ \\ Saadiyah Darus ${ }^{2}$ \\ Nazia Hussain $^{3}$ \\ ${ }^{1}$ Department of Humanities \\ Bangladesh University of Engineering and Technology \\ E-mail: mizanurrahman@hum.buet.ac.bd \\ ${ }^{2}$ School of Language Studies and Linguistics \\ Faculty of Social Sciences and Humanities \\ Universiti Kebangsaan Malaysia \\ E-mail: adi@ukm.edu.my \\ ${ }^{3}$ Department of World Religions and Culture \\ University of Dhaka, Bangladesh \\ E-mail: lena_du@yahoo.com
}

\begin{abstract}
This paper attempts to investigate whether or not the English competency of Customer Service Representatives (CSRs) is hindering the growth and development of outsourced call centers in Bangladesh. It also looks into the problems being faced by call centers in hiring English competent CSRs. A limited appraisal of the English communication training of the CSRs offered by Call Centre Training Institutes is also within the purview of the paper. With this purpose 33 supervisors of different call centers, who are in charge of monitoring the CSRs, have been interviewed with a questionnaire comprised of both close and open ended questions. The result shows there is scarcity of skilled English communicators which is one of the major barriers in the growth and development of the call centers. However, factors like product knowledge, intercultural communication skills, service personality are also crucial as they are integral for successful transaction and addressing them will pave the way for the progress of the industry. The result also implicitly indicates that mainstream education system in Bangladesh is still unable to produce competent English communicators. The findings of the study reveal that the current shortage of skilled manpower can further become more acute when call center industry grows in line with the expectation of the government. It is also revealed that the call center training institutes are incapable of delivering the kind of training required for the aspirant CSRs. This study pinpoints the necessity of future research in several directions to ensure a balance between the demand and supply of native like fluent English communicators for call center Industry in Bangladesh.
\end{abstract}

Keywords: English language competency, outsourced call centers, CRRs 


\begin{abstract}
Abstrak
Tulisan ini mencoba untuk menyelidiki apakah kompetensi bahasa Inggris Perwakilan Layanan Pelanggan (Customer Service Representatives/CSR) menghambat pertumbuhan dan perkembangan pusat-pusat panggilan pengalihluaran di Bangladesh. Tulisan ini juga menyelidiki masalah yang dihadapi oleh pusat panggilan dalam mempekerjakan CSR yang berkompeten dalam bahasa Inggris. Sebuah penilaian terbatas dari pelatihan komunikasi bahasa Inggris bagi CSR yang ditawarkan oleh Lembaga Pelatihan Pusat Panggilan akan menjadi pembahasan dalam artikel ini. Untuk mencapai tujuan ini, 33 pengawas dari pusatpusat panggilan yang berbeda, yang bertugas memantau CSR, telah diwawancarai dengan kuesioner terdiri dari pertanyaan tertutup dan terbuka. Hasilnya menunjukkan ada kelangkaan staf yang terampil dalam bahasa Inggris yang menjadi salah satu hambatan utama dalam pertumbuhan dan perkembangan pusat panggilan. Namun, faktor-faktor seperti pengetahuan produk, kemampuan komunikasi antarbudaya, kepribadian layanan juga berperan penting karena semuanya merupakan bagian integral transaksi yang berhasil dan upaya peningkatan semua faktor tersebut akan membuka jalan bagi kemajuan industri. Hasilnya juga secara implisit menunjukkan bahwa sistem pendidikan utama di Bangladesh masih mampu menghasilkan individu yang berkompeten dalam bahasa Inggris. Temuan penelitian ini juga mengungkapkan bahwa kekurangan tenaga kerja yang terampil dapat menjadi lebih parah ketika industri pusat panggilan tumbuh sejalan dengan harapan pemerintah. Terungkap juga bahwa lembaga pelatihan pusat panggilan tidak mampu menyediakan jenis pelatihan yang dibutuhkan oleh para calon CSR. Penelitian ini menunjukkan perlunya penelitian masa depan di beberapa aspek untuk memastikan keseimbangan antara permintaan dan pasokan individu yang fasih berbahasa Inggris seperti penutur jati untuk Industri pusat panggilan di Bangladesh.
\end{abstract}

Kata kunci: Kompetensi bahasa Inggris, pusat panggilan pengalihluaran, CSR

\section{INTRODUCTION}

The growing influx of outsourced call centers in some developing nations has raised the concern for English communication competency of the Customer Service Representatives (CSRs) who are in charge of handling the offshore clients. Since 199 os customer service call centers of many developed nations have been shifted to countries with available human resources and cheap labor in order to trim running cost of business and to maximize the profit. (Friginal, 2007). In 2010 there was a US\$390 billion market worldwide for outsourced call centers. India and Philippines claim a major portion of worldwide Business Process
Outsourcing (BPO) market. For the fiscal year 2009 - 2010 Bangladesh government expected to grab $1 \%$ of the BPO market which was equal to around US\$ 4 billion, but regrettably Bangladesh has managed to earn only (approx.) US\$ 2 million by last one and half year from this sector. (The Daily Prothom Alo, 2010). Gartner (a US based information technology research and advisory company that provides technology related insight), in its 2010 rating included the name of Bangladesh in the top 30 locations for outsourcing destinations in the world. Bangladesh fared well in almost every criterion that determined Gartner's top 30 locations for outsourcing. However, language 
proficiency of Bangladesh was identified as 'poor' (The Daily Star, 2010).

The outsourced call centers in Bangladesh have started working with a lot of expectations to usher in foreign currency vis-a-vis ready made garment and manpower sector - two of the foremost contributing sectors for the national economy. The ministry of telecommunication and ministry of trade and commerce identifying the tremendous possibilities of outsourced call centers in generating foreign currency and job opportunities in Bangladesh declared several incentives for this sector. Bangladesh Telecommunication Regulatory Commission (BTRC) is in the process of formulating competitive tariffs and supportive facilities for this sector. According to the call center guidelines formulated by BTRC, entrepreneurs are enjoying tax holidays for a maximum of five years and get bank and remittance without hassle. The potentials of outsourced call centers have been the subject of discussion even in the national parliament which certainly shows the priority that government has set for promoting this industry. (Outsource, 2012)

Finding competent English language communicators continues to be one of the major barriers for the establishment and growth of the outsourced call centers in Bangladesh. (The Daily Prothom Alo, 2010; Gartner, 2010 cited in The Daily Star, 2010) The mainstream Bangla medium educational institutes where the medium of instruction is the mother tongue Bangla receive English as Foreign Language courses from Grade 1 to Grade_12. Taking cognizance of the importance of English for academic purposes English language courses have been introduced at undergraduate levels across disciplines with initiatives from university Grants Commision of Bangladesh (Raynor, 1995). Even after receiving English lessons for all these years, very few of them become proficient in English skills as a number of deficiencies is prevalent in the country's English education scene (Farida, 2008; Khan, 2000). However, the concern over English communication skills is also noticeable in other Asian call centers. There are examples that despite huge investment, the call centers are plagued by the problems of language training and assessment of CSRs (Lockwood, 2012).

Since April 2008 Bangladesh

Telecommunication Regulatory Commission (BTRC) started providing license for outsourced call centers without ensuring any minimum requirement. What the call centers needed for getting license is by only submitting Tk. 5000 (approximately U\$70) to BTRC. Since then 489 Call Centers got license for operation from BTRC. Among 37\% of these call centers, $11 \%$ have surrendered their licenses and 26\% have their licenses cancelled by BTRC for not being able to enter into operation within the first six months after getting the license. BTRC cannot trace 238 call centers that have been granted license for operation. According to BTRC, 70 call centers are maintaining their operation and among them only 35 are maintaining it satisfactorily. These call centres are located in Dhaka (30), Chittagong (4) and Sylhet (1). But BACCO (Bangladesh Association of Call Centers and Outsourcing) confirms that only 33 call centers cannot even indulge in full operation because of problems like lack of skilled manpower and necessary facilities that they expect from the government. BACCO also confirms that for the same reasons, 300 call centers have failed to start their operation even after getting their license. BTRC and BACCO detect that skilled manpower, (in other words, competent English communicators), power disruption and no back up in international fiber optic cables is some of the foremost hindrances that should be addressed urgently.

English is taught as a compulsory
second language (L2) subject in


elementary, secondary and higher secondary schools in Bangladesh. It is assumed that by the time students begin their tertiary studies after studying English for 12 years, they have a reasonably good standard of English language proficiency. However, this is not the actual scenario. 1990s saw the entry of Communicative Language Teaching methods in the classroom of Bangladesh and the introduction of "a set of supposedly communicative English textbooks entitled English for Today" (Siddique 2004: 16). Such a communicative syllabus was introduced on the recommendation by British ELT experts recruited to rectify the effects created by the marginalization of English in the post-independence period. In the secondary and higher secondary school levels, the national curriculum textbook board (NCTB) from 1995 recommended only one English book, English for Today, which has numerous units of skill based comprehension work based on short non-fiction passages. Recently, this book has been supplemented with one grammar book. The aim of introducing English for Today was to teach English as a language of communication, not as a subject of knowledge. This transition took place with the purpose of helping students express themselves using the L2. Unfortunately, however, the objective failed to serve its purpose which was evident from the proficiency of the students entering into universities or in job market in the consecutive years.

Studies by Alam (2002), Hasan (2004), Siddiqui (2004), Sinha (2005), Ahmad (2005), Hamid (2006) have revealed numerous practical problems in connection with CLT and English for Today for the Bangladeshi classroom. Although the curriculum expects students to use all the language skills in learning English and transferring those skills in real life situations, in reality that is hardly what is practiced. There are cases where students do not even use that single core book, and simply practice the solved exercises available in low quality guide books or consult private tutors who only help the students by showing ways of getting good score in English other than mastering the English skills. Consulting English private tutors to get a good grade in English is a very common practice in Bangladesh. It is the firm belief of students and guardians that English cannot be learnt without private tutors. Moreover, the English teachers are heavily reliant on private tuitions for their income since the pay structure in the educational institutions is very low compared to the high inflation in the economy. As a result, most teachers teach carelessly in the classes and students feel compelled to attend private coaching. (Hamid et al. 2009).

Apart from the Bangla medium schools, there are also some private English medium schools that enjoy an elite status and do not follow the national curriculum. They have their own syllabus, use textbooks mainly produced in the UK and India. These students sit for 0 and $\mathrm{A}$ level examinations administered by the British Council and eventually go abroad to continue their studies.

Until the mid-1980s English was a compulsory subject for the Bachelor of Arts (Pass) degree program (Years 13 and 14) but was dropped from the BA (Pass) degree syllabus in order to increase the pass percentage. After one and a half decade from the 1996-1997 academic session, the government of Bangladesh reintroduced English as a compulsory subject at the tertiary level. In 2001, the government again decided to declare English as a second language most probably due to the recent upsurge of privatization and globalization in every sector (Zaman, 2003, 2004)

Realizing this complex situation and for the purposes of allowing students to overcome their language problems and to reach the target level of English language proficiency, public universities in Bangladesh have been encouraging 
faculties to introduce compulsory English language courses for the first year students of different Departments (Dutta, 2001). It is true that not all departments need English to cope with their undergraduate studies, but there are subject areas that rely heavily on good English language competence, though for their future professional life English proficiency is essential irrespective of their departments. If students seriously intend to do well they need to read and consult books and journals mainly written in English. But as students are weak in English they find themselves in an almost helpless situation unable to make ends meet. Hence, the reason for such inclusion of English language courses is obviously because different departments, irrespective of their different disciplines, feel that English is immensely beneficial and necessary for the students undertaking higher studies. However, it is observed that these courses tend to be simply remedial and general in nature focusing mainly on the teaching of the four skills with a special emphasis given to deductive grammar teaching. The departments fail to recognize the students' specific needs as well as the institutional needs and thereby fail to make their language programs successful or enhance students' linguistic competence (Ahmed, Alam \& Farida, 2004).

Apart from the problematic macro structure of English education system there are several problems at the ground level. Firstly, the class size of Bangladesh is one of the biggest in the world. The size of a language classroom according to the experts should be confined to 20-30 students. A typical Bangladeshi classroom, however, is always overcrowded with more number of students than the ideal. As a result, teachers cannot give adequate attention to an individual student in the class. Secondly, there is scarcity of resources in Bangladeshi classroom that cause hindrance to effective language classes. Among others the unavailability of teaching tools for arranging listening sessions in the English classes is most prominent. English teachers in most of the educational institutions across the country cannot arrange listening activities which result in practice of one of the important skills of language totally ignored (Khan, 2000)

Moreover, pre-service and inservice training is essential for the English teachers so that they can teach effectively. To make the English courses effective across the country a large pool of trained teachers are required. Regrettably most of the teachers in Bangladesh enter into the profession without any prior training (Khan, 1999) and many of the teachers end their teaching career without attending any kind of training program. Rigorous preservice training is indispensable that can help teachers among others to address and identify the areas of teaching where they should concentrate. Moreover, for continuous professional development and to cope up with the changes take place in syllabus or curriculum in service training should be offered at regular interval which is not visible in Bangladeshi teaching scene. It can be inferred from the picture of English education drawn above that from elementary to tertiary level our education system cannot produce proficient English communicators.

Research gives importance on the cultural, institutional and discipline practices as the beginning of an ESP curriculum for call centers (Lockwood, 2012). However contextual and situational understanding of the New Rhetoric and interdisciplinary approach i.e. ESP for business, have been considered equally important to cover language, interpersonal communication skills, business and cultural issues (St. John, 1996). Therefore, ESP curriculum research for call centers has drawn mainly on three schools which are basically different ESP approaches to Genre analysis. The first is the ESP approach developed by Bhatia (1993) and Swales (1998) "that explores genres, particularly academic and professional 
genres, identifying a schematic structure exhibited by communicative functions" (Lockwood, 2012, p. 16) For methodical investigation of new sites such as outsourced call centers, Bhatia's (1993) different ways of genre analysis have provided very useful framework for ESP genre researchers. The second is systemic functional linguistic framework that "investigates meaning through its tripartite framework - the ideational (field), interpersonal (tenor) and textual (mode), and describes and links lexicogrammatical choices and register to this larger socio-cultural framework" (Lockwood, 2012, p. 16). First developed by Halliday $(1978,1985)$ and later expanded by Hood \& Forey (2008), Martin (1992), Martin \& White (2005) came to be known as Sydney School. The third school "emphasizes the fluidity of genres and the notion of intertextuality" and "[T] his school is more concerned with the context of what is being described and the purpose of the text as a way of explaining language" (Lockwood, 2012, p. 16). This school is known as Rhetorical Genre Studies developed by Bazerman (1994) and Hyon (1996). For obvious reasons then current research on call center discourse is conducted through sociolinguistic perspectives as it can accommodate cultural and contextual understanding within language communication training program.

This paper attempts to investigate whether or not the English competency of CSRs is hindering the growth and development of outsourced call centers in Bangladesh. It also looks into the problems being faced by call centers in hiring English competent CSRs and attempts to appraise the role of Call Centre Training Institutes in assisting the aspirant CSRs to be successful in providing effective service to English speaking customers. There are certainly many factors involved in the determination of success in service delivery in the context of outsourced call centers and English competency might just be one of the factors. This forms the basis of sociolinguistic framework for current research in ESP language training programs for call centers as the framework incorporates multiple factors. Informed by current theoretical approaches to ESP language training programs and the observation of supervisors of outsourced call centers this study aims to provide significant information which will have implications for language training directions for Bangladeshi call centers in the future.

\section{METHOD}

The data for the present study were collected by means of a questionnaire survey among 33 Supervisors (who are in charge of monitoring the CSRs and overall supervision of the transactions performed in the call center floor) of the call centers. 46 call centers were selected on the basis of those who got approval (in the form of license) from BTRC and obtained membership of BACCO but we were able to reach only 33 of them. The rest of them either is not in operation or cannot be contacted.

The participant Supervisors were at least a general graduate or a graduate either in business studies or engineering. The majority of them (28) had been in the profession from the beginning (i.e. since April 2008) and the remaining 5 had worked for around a year or so.

The questionnaire (see Appendix A) focused on a wide range of issues, such as the major challenges or barriers to the growth of the call centers, shortage of competent communicators in the country, problems of hiring agents, importance of training etc. Questions were both close and open-ended, and participants even in close ended questions were given the provision to further explain their opinions as detailed as they wished. Despite the challenge involved in interpreting and analyzing free-form qualitative data, this in-depth type of inquiry was preferred since a single 
instrument for data collection was used, giving respondents freedom to express their views in the format of open-ended questions which would make up for the absence of a follow-up interview or group discussion or interview of the agents which, however desirable, could not be arranged because of practicality constraints.

\section{RESULTS AND DISCUSSION}

The data was analysed manually by using content analysis. The participants' replies to any particular question were read thoroughly, the views expressed were summarized and tabulated on a wordprocessor. The summaries of the participants' responses were divided into as many categories as they were amenable to and the numbers in each of the categories had been counted. This was not to give the impression that the responses automatically fell into this or that category. In fact, their responses to the questions varied and some were occasionally marked by inconsistencies and contradictions (see Discussion below). However, closer readings of the responses, cross-comparing and categorizing aided in translating the raw data into interpretable findings. The information drawn from the responses through the interviews are presented in the next section. A summary is also provided in Table 1.

\section{Main Hindrances to the Growth of the}

\section{Sector}

This was a close question which contained four different options for the respondents to choose one or more, plus an additional option of writing their own response in the space provided. 24 respondents identified that the main hindrance of this sector is the lack of competent English speakers. This was followed by 7 responses for option two that the country has no back up in international fiber optic cables. There was also 1 response that detected option three, which is inadequate power supply. Only one respondent volunteered to write his own answer in addition to choosing the option of "Inability to attract large international market". He was guided by the belief, he wrote, "Unlike NRIs (Non Resident Indians) NRBs (Non Resident Bangladeshies) are not playing any role for the growth of the sector".

\section{Problems of Hiring CSRs}

The respondents expressed diverse views on the problems of hiring agents. Most of the call centers find that when they want to recruit agents there are overwhelming number of applicants but very few of them are eligible for working as agents. They have found it that only students of English medium background (those who follow the British curriculum) are proficient in English communication, there is an insignificant number of mainstream Bangla medium students (those who follow the national curriculum) have proven their ability to become agents. It was revealed from the answers of the questionnaire that the students coming out from Madrasahs even do not apply for these positions though in Bangladesh each a year a large number of students get admitted to Madrassahs. ${ }^{1}$ But the respondents have pointed out that if they offer an amount of salary around BDT 20,000 (approx. US\$ 285) or more per month then they can manage to get qualified agents (of course they are from English medium institutions). Nevertheless, respondents pointed out that since the students of English medium schools are from solvent families most of them do not show the kind of dedication and commitment towards their jobs that are essential for the growth and development of any sector. Apart from that working in the night shifts (in the case of doing business with North American countries the agents have to work in the 
night shifts) is another major problem for the agents. Most of the agents are reluctant to work in the night shifts especially the girls who or their guardians are very concerned when they work in the night shifts. Additionally, there is a lack of awareness in Bangladeshi society that still cannot consider call center related jobs as something which someone can take as his/her career.

Table 1: Participants Responses to the Questions Surveyed

\begin{tabular}{|c|c|c|c|}
\hline Questions & $\begin{array}{l}\text { Question no. in } \\
\text { questionnaire }\end{array}$ & Summaries of responses & $\begin{array}{l}\text { No. of } \\
\text { informants } \\
\text { (Total 33) } \\
\end{array}$ \\
\hline $\begin{array}{l}\text { What are the main hindrances to the } \\
\text { growth of this sector? }\end{array}$ & Q.6 & $\begin{array}{l}\text { Lack of competent English communicators } \\
\text { No back up in international fiber optic } \\
\text { cables } \\
\text { Inadequate Power Supply } \\
\text { Inability to attract large international } \\
\text { market }\end{array}$ & $\begin{array}{l}24 \\
7 \\
1 \\
1\end{array}$ \\
\hline $\begin{array}{l}\text { Do you find scarcity of proficient English } \\
\text { communicators while recruiting CSRS for } \\
\text { your call center? }\end{array}$ & Q.7 & $\begin{array}{l}\text { Yes } \\
\text { No }\end{array}$ & $\begin{array}{c}33 \\
0\end{array}$ \\
\hline $\begin{array}{l}\text { How are your agents' English language } \\
\text { competency? }\end{array}$ & Q. 10 & $\begin{array}{l}\text { Very good } \\
\text { Good } \\
\text { Fair }\end{array}$ & $\begin{array}{c}9 \\
19 \\
5\end{array}$ \\
\hline $\begin{array}{l}\text { Which is the major challenge for your } \\
\text { agents while communicating with the } \\
\text { clients? }\end{array}$ & Q.12 & $\begin{array}{l}\text { Successful communication in English } \\
\text { Product / Marketing knowledge }\end{array}$ & $\begin{array}{c}8 \\
25\end{array}$ \\
\hline $\begin{array}{l}\text { Do you think there should be rigorous } \\
\text { pre-service and in service training } \\
\text { programs for the agents to improve their } \\
\text { English communication competence? }\end{array}$ & Q.14 & $\begin{array}{l}\text { Important } \\
\text { Not important }\end{array}$ & $\begin{array}{c}33 \\
0\end{array}$ \\
\hline $\begin{array}{l}\text { Have the agents recruited for your call } \\
\text { center undertaken pre-service training? }\end{array}$ & Q.15 & $\begin{array}{l}\text { Yes } \\
\text { No }\end{array}$ & $\begin{array}{c}5 \\
28\end{array}$ \\
\hline $\begin{array}{l}\text { Do you offer in service training for your } \\
\text { CSRs }\end{array}$ & Q.16 & $\begin{array}{l}\text { Yes } \\
\text { No }\end{array}$ & $\begin{array}{c}33 \\
0\end{array}$ \\
\hline $\begin{array}{l}\text { How, do you think, we can build up } \\
\text { skilled English communicators as the } \\
\text { CSR for our call centers? }\end{array}$ & Q.18 & $\begin{array}{l}\text { Rigorous English courses be offered in } \\
\text { Educational institutions } \\
\text { Apart from educational institutions English } \\
\text { courses be offered in other training centers } \\
\text { English course be offered by the call centers } \\
\text { to make their agents proficient in English }\end{array}$ & $\begin{array}{l}22 \\
7 \\
4\end{array}$ \\
\hline
\end{tabular}

\section{The Importance of Training}

Both pre-service and in-service training were considered as very important factors by the respondents for improving the proficiency of English skills of agents beside several other things. While the preservice training helps the aspiring agents to become aware of the responsibilities that they are going to undertake as agents and helps improve their English skills, the in-service training is essential for agents to get accustomed with the nature of jobs of a particular call center and let them gather some first hand experiences that they are going to accomplish after taking a position in their respective seats. A respondent noted:

If the agents are trained prior to their joining in the call centers, it is easier for them to follow the necessary instructions while serving; but I have experiences that a lot of agents are not properly / poorly trained in the commercial training centers and I have either not recruited them or found it difficult to make them adapt with requisite responsibilities as agents. 


\section{The BTRC approved Call Center Training Institutes}

Participants pointed out that Call Center Training Institutes (CCTI) have failed to produce skilled manpower who can successfully work as agents in the call centers. ${ }^{2}$ Most of the participants are of the same opinion that there are very few skilled personnel coming out of those CCTIs and they can hardly show their competence while asked for interviews. While asked about the reasons for CCTIs failure to produce skilled personnel for call centers, most of the participants opined that there is a huge dearth of good trainers in those institutes.

One participant wrote,

"Though there are some experienced Indian trainers working in few training institutes, many of the trainees are found without having the very basics of English",

Ultimately, he added,

"the trainees though get certificates form those institutes, they do not turn out to be proficient communicators and cannot join as agents as promised by the training institutes".

One of the crucial revelations of this research is that the CCTIs are not running properly, i.e. they lack good trainers and adequate infrastructures without which they cannot function properly. There is the existence of an accreditation committee named TIAC (Training Institute Accreditation Committee) ${ }^{3}$ to ensure quality in every aspects of training of agents, but it exists only in paper.

\section{How to Build up Proficient Communicators for Call Centers?}

"English should be taught with a view to improve the communication skills of the students. With this aim in view from elementary to tertiary level there should be rigorous emphasis on improving students' English skills especially speaking and listening skill". Opined a supervisor. A group of 22 supervisors subscribed to this or similar views. However, 9 managers pointed out the necessity of offering special courses on English in training institutes that will help develop the communication skills of the students together with making them competent as would be agents working in the call centers. 2 of them were of the view that rigorous English courses should be offered by the Call Centers themselves with expert trainers and effective syllabus that can ensure English communication proficiency of the CSRs. On the other hand, two observant supervisors felt that "Bangladesh is badly in need of good English teachers / trainers". They explained that, "If we do not have good teachers / trainers ultimately we cannot expect to get competent English communicators coming out of our educational /training institutes". So they felt the exigency of properly trained teachers of English who can facilitate the building up of proficient communicators for Bangladesh in general and for our call centers in particular.

The views expressed by the informants regarding the issues were rich and diverse, but some broad tendencies are discernible. We will now discuss these with several caveats. The study reveals that most of the participants consider the scarcity of proficient English communicators as a major barrier to the growth and further development of this sector. They, however, have also noted that there are some other important factors (mentioned in the optional choices to the answer of Q. 6) that should also be addressed immediately to help flourish the sector. But the mentioning of the scarcity of competent English communicators is contradictory to some extent because some informants pointed out (while explaining 
the answer of the question on "problem of hiring agents") that when the pay structure is high (BDT 20,000 or more) they get proficient communicators as CSRs. Again, a call centre with goodwill and reputation can rather easily employ good communicators of English. But the reality is that in this sector there are very few call centers with goodwill and reputation or can pay high because it is not more than a couple of years that these call centers have entered into business and most of them have not yet made any profit from their business. So, responses on scarcity of competent English communicators though marked by contradictions, is certainly one of the foremost causes that hinders the expected growth and development of the call centers in Bangladesh.

The reasons for the scarcity of skilled English communicators are - the mainstream Bangla medium and Madrassah education cannot produce communicators with near native English fluency, the English medium students show a tendency of not taking their jobs seriously, the call centers do not afford to pay an attractive salary package for the agents, and above all Bangladeshi society is still not considering call center related jobs potential enough to choose them as one's career since there is a lack of awareness in the society about this sector that it can turn out to be a huge foreign currency generating sector beside readymade garment or manpower sector. The data highlights the fact that the communication ability of those who are currently working as agents is "good" but still most of the employers have to struggle to get good communicators. Only 2 among the 33 call centers have adequate CSRs as they have high reputation in the job market and their pay structure is higher compared to others Therefore, when the industry sees its growth and when the already approved call centers start operating together with new entrepreneurs planning to come to this business - there will be a huge dearth of skilled English communicators.
The respondents provided unanimous opinion on the necessity of preservice and in-service training for the agents. But they have expressed their dissatisfaction over the quality of training in CCTIs or in other English training institutes. It is found that though CCTIs get approval from BTRC, even then quality is not maintained in the CCTIs. Most of the CCTIs do not have necessary infrastructure, qualified trainers or up to date course materials. TIAC, the accreditation committee even has failed to oversee the CCTIs. Therefore, the role of TIAC comes to the forefront in ensuring the quality of training in CCTIs. However, the in-service training offered by the call centers has been proven to be effective and successful.

The study sheds light on the fact that our mainstream Bangla medium educational institutions are still not fully capable of creating an English skilled generation. Perceptions on building communicative competence differed from one another. Some participants suggested only for effective English courses in the educational institutions while others recommended that there should be "special" training courses on English in training institutes (apart from the general English courses that they offer) strongly monitored by TIAC. But since the entire gamut of English teaching-learning environment is in a mess in the country there should be very cautious steps towards determining what should be the means of improving English communication skills of the learners for not the call centers alone but for Bangladesh in general.

\section{CONCLUSION}

Outsourced call center Industry of Bangladesh is facing a major setback as they are not getting competent CSRs who are proficient in English communication and meet the expectations of overseas English speaking customers. The levels of professional English spoken by the 
university graduates of Bangladesh are unable to meet the demands of English speaking customers. However, with the given English education and appropriate training will allow these CSRs to work in outsourced call centers and attain adequate achievement.

The findings of the study reveal that there is shortage of skilled manpower who can serve these call centers which will turn into an acute problem when call center industry grows in line with the expectation of the government and the training institutes are still incapable of delivering the kind of training required for the aspirant CSRs. This study pinpoints the necessity of future research in several directions to ensure a balance between the demand and supply of native like fluent English communicators for call center industry which are discussed below.

The result of the present study is based on the interview of supervisor of the call centers. There are some limitations in not including the actual customers' view about the linguistic competence of the CSRs. The supervisors do the assessment through listening to the recorded transactions handled by the CSRs. Though the supervisors are in charge of monitoring the performance of the CSRs and they have wide experience in this field, future research focusing on assessment of CSRs linguistic performance by the overseas callers will provide more useful information.

Apart from high level of English proficiency, other factors certainly contribute in successful transaction. Research carried out on Filipino call centers (Friginal 2007, 2012, Lockwood, 2012) shows that product knowledge, intercultural communication skills, service personality etc. vis-à-vis language skills are required by the non-native CSRs to provide effective service to American customers. Therefore, the sociolinguistic framework for current ESP Language Training program can be invaluable though needs analysis has to be conducted to identify the specific needs of communication competency and other factors that make successful transaction in the context of outsourced call centers in Bangladesh.

BTRC approved call centers are not functioning according to the expectation. Though language training of Filipino call centers also have limitations (Friginal, 2007), they are continuously improving (Lockwood, 2012). It is clear that they are performing better than the Bangladeshi call center training institutes. The reason is comprehensive research has been carried out to investigate how these training centers might offer more effective training for the CSRs and those research findings have been strictly administered to improve the performance of the CSRs. Therefore, similar research on Bangladeshi context can be undertaken for improving the performance of the CSRs of Bangladeshi call centers. It is noteworthy that call centers in Philippines offer in house training both for language proficiency and for service delivery. These call centers even hire university level Teaching of English as a Second Language (TESL) instructors to assess the linguistic performance of the CSRs (Friginal, 2012). Call centers in Bangladesh also provide inhouse training but no supervisor in this study has reported that they involve language experts for the CSRs' assessment. As involving TESL professionals with training and assessment process has better outcome, it should be seriously considered in the case of Bangladeshi call centers.

Finally, language concern is the focus of this study; nevertheless it reveals that language is one of the many factors required for handling successful transaction of the call centers. Thereby, it is the contention of the researchers that inputs from the concerned stakeholders i.e. the entrepreneurs, Ministry of Commerce, Bangladesh Telecommunication Regulatory commission (BTRC), Ministry of Education and English language policy 
makers, all of them should work together to address the issues discussed here to overcome the major setbacks of outsourced call centers including the scarcity of proficient English communicators for the call centers.

\section{ACKNOWLEDGMENTS}

We are greatly indebted to Abed Chowdhury (a gene scientist) and Munir Hasan (General Secretary, Bangladesh Math Olympiad Committee) whose joint article on English proficiency of our young generation (published in one of the issues of The Daily Prothom Alo in mid-2010) first drew the first author's attention on the scarcity of competent English communicators in the Call Centers of Bangladesh.

\section{REFERENCES}

Ahmad, S. N. (2005). The application of communicative language teaching in Bangladesh. Dhaka University Studies. Journal of the Faculty of Arts. 1: 191-200.

Ahmed, T., Alam, Z. \& Farida, N. (2004). Mapping out new directions for English at the universities, Paper presented at the BELTA (Bangladesh English Language Teachers' Association) National Conference held at British Council, Dhaka.

Alam, F. (2002). Using postcolonial literature in ELT. The English Teacher: An International Journal. 5/2: 123-136.

Bazerman, C. (1994). Systems of genre and the enactment of social interaction. In P. Freedman \& P. Medway (Eds.), Genre and the new rhetoric (pp. 79-99). London: Taylor \& Francis.
Bhatia, V. (1993). Analysing genre: Language use in professional settings. London: Longman.

Farida, N. (2008). A textual and contextual study of English language and literature essays: The case of First Year English Department students' writing in Dhaka University, Bangladesh. Unpublished Ph.D thesis, Centre for Applied Linguistics, University of Warwick.

Friginal, E. (2007). Outsourced call centers and English in Philippines. World Englishes 26/3: 331-345. -. (2012). Evaluation of oral performance in outsourced call centres: An exploratory case study. English for Specific Purposes. 32/1: 25-35

Hamid, O. (2006). An apology for contentbased instruction. Department of English, University of Dhaka Publication. Spectrum. 4: 80- 96

Hamid, O., Susse, R., \& Khan, A. (2009). Private tutoring in English for Secondary Englsih school students in Bangladesh. TESOL Quarterly. 43/2: 281-308

Halliday, M. A. K. (1978). Language as social semiotic: The social interpretation of language and meaning. London: Edward Arnold.

(1985). An introduction to functional grammar. London: Edward Arnold.

Hasan, M. K. (2004). A linguistic study of English Language curriculum at the secondary level in Bangladesh: A communicative approach to curriculum development. Ph.D Thesis. Language in India. 4. Retrieved on 20/4/2008 from<http: //www.languageinindia.com/aug2 
004/hasandissertation/htm\#chap3 $>$

Hood, S., \& Forey, G. (2008). The interpersonal dynamics of call centre interactions: Coconstructing the rise and fall of emotion. Discourse and Communication, 2(4), 389-409.

Hyon, S. (1996). Genre in three traditions: Implications for ESL. TESOL Quarterly, 693-722.

Khan, R. (1999). An Evaluation of the Writing Component of the Higher Secondary English Syllabus in Bangladesh. Unpublished $\mathrm{PhD}$ thesis: Centre for English Language Teacher Education, University of Warwick.

(2000). The English

Foundation Course at Dhaka University: An Evaluation." The Dhaka University Studies, 57/1: 77-110.

Lockwood, J. (2012). Developing an English for specific purpose curriculum for Asian call centres: How theory can inform practice. English for Specic Purposes. 31: 14-24

Outsource. (2012). Bangladesh another South Asian sourcing hotspot. Retrieved on 12.02.2014 from http://bacco.org.bd/outsource.pdf

Martin, J. (1992). English text: System and structure. Amsterdam: John Benjamins.

Martin, J., \& White, P. (2005). The language of evaluation: Appraisal in English. London: Palgrave Macmillan.

Raynor, J. (1995). Introduction of Compulsory English Language at the Tertiary Level: a Study Undertaken by British Council on behalf of University Grants Commision. Dhaka: The British Council

Siddiqui, R. (2004). Teaching non-native literatures in English in the global
English Language classroom. Unpublished M.A thesis: CELTE University of Warwick

Sinha, B. S. (2005). Our English achievement tests and what we really achieve. Spectrum. 1: 23-26

St. John, M. J. (1996). Business is booming: Business English in the 1990's. ESP Journal, 15(1), 3-18.

Swales, J. (1998). Other floors, other voices: A textography of a small university building. Mahwah, $\mathrm{NJ}$ : Lawrence Erlbaum.

The Daily Prothom Alo. (2010, 25 Aug.). "Share Charsho Call Center Kaj Shurru Korte Pareni" (Four Hundred and Fifty Call Centers Have Failed to Start Operation). Retrieved 12 Feb. 2014 from http://www.eprothomalo.com/inde x.php?opt $=$ view \& page $=3 \&$ date $=2$ 010-08-25

The Daily Star. (2010, Dec. 27). "Bangladesh among best spots for IT outsourcing".

The Daily Star. (2010, Apr. 25). "Call Center: The Sky is the Limit".

Dutta, S. K. (2001). English language and literature in Bangladesh: towards a methodology. In Alam, F. Zaman, N. and Ahmed, T. (eds.). Revisioning English in Bangladesh. Dhaka: UPL

Zaman, N. (2003). English. In Islam, S. (ed.) Banglapedia: National Encyclopedia of Bangladesh Vol 3. Asiatic Society of Bangladesh: 486-491

(2004). National language policy. Bangladesh in the New Millennium: A University of Dhaka Study. Kalam, A. (ed.). Dhaka. University Press Ltd.: 203-213. 


\section{NOTES:}

${ }^{1}$ Besides Bangla and English medium educational institutions Bangladesh has Madrasahs or schools where emphasis is placed on religious studies. Ebtedai, Qaumi, Hafizia, and Alia Madrasahs have prominent place in our education system in terms of enrolment. But only the Alia Madrasahs in addition to religious studies offer courses on English language, science and humanities or social sciences. The enrolment number in Alia Madrasahs in 2006 is 3.45 million. (Souce: Statistical Pocket Book Bangladesh 2006)

2 A CCTI is a place, where Call Center Agent(s) and related personnel are trained to operate as agent/operator for any call center. These institutes run commercially for imparting call center related training. Bangladesh Telecommunication regulatory commission (BTRC) realizing the necessity of quality training of CCTIs made it mandatory to obtain license from BTRC prior to establishment of any CCTI.

${ }^{3}$ TIAC is formed with a view to ensure internationally acceptable quality training by means of well trained faculty, excellent learning environment, up to date curriculum and many more promises to facilitate growth of Call Centre Training Institutes (CCTIs) in Bangladesh and, in turn, Call Centre industry by ensuring quality in every aspects of training of agents. 